\title{
PENERAPAN METODE JIGSAW DAPAT MENINGKATKAN HASIL BELAJAR IPA PADA MATERI PESAWAT SEDERHANA DI KELAS V SD NEGERI SUMBER KECAMATAN KARANGAN KABUPATEN TRENGGALEK TAHUN 2016
}

\author{
Suroso \\ SDN Sumber, Karangan, Trenggalek \\ email:suroso@gmail.com
}

\begin{abstract}
Based on the results of observations in SD Negeri Sumber, Karangan, Trenggalek Regency, it was found that cases were found that there were problems in the applied learning, the teacher only used the lecture method and never used other learning methods. This type of research is action research and uses Kemmis and Mc Taggart designs. Based on the results of the first cycle test data obtained an average class value of $57.89 \%$ the results of the second cycle test obtained an average grade of $89.47 \%$. The results of the average class score in cycle 1 and cycle 2 are known that student learning outcomes in the cognitive domain by applying the jigsaw method increased by $31.58 \%$.
\end{abstract}

Keywords: Jigsaw Method, Science Learning Outcomes

\begin{abstract}
Abstrak: Berdasarkan hasil observasi di SD Negeri Sumber Kecamatan Karangan Kabupaten Trenggalek menunjukkan bahwa ditemukan kasus bahwa terdapat masalah di dalam pembelajaran yang diterapkan yaitu guru hanya menggunakan metode ceramah saja dan tidak pernah menggunakan metode-metode pembelajaran lainnya. Jenis penelitian ini adalah penelitian tindakan dan menggunakan desain Kemmis dan Mc Taggart. Berdasarkan data hasil tes siklus 1 didapatkan rata-rata nilai kelas sebesar 57,89 $\%$ hasil tes siklus 2 diperoleh rata-rata nilai kelas $89,47 \%$. Hasil rata-rata nilai kelas pada siklus 1 dan siklus 2 diketahui hasil belajar siswa pada ranah kognitif dengan menerapkan metode jigsaw meningkat sebesar $31,58 \%$.
\end{abstract}

Kata Kunci: Metode Jigsaw, Hasil Belajar IPA

\section{PENDAHULUAN}

Pendidikan adalah usaha sadar dan sistematis, yang dilakukan oleh orang-orang yang diserahi tanggung jawab untuk mempengaruhi peserta didik sehingga mempunyai sifat dan tabiat sesuai dengan cita-cita pendidikan (Daryanto, 2011:1). Dalam arti lain, pendidikan merupakan pendewasaaan peserta didik agar dapat mengembangkan bakat, potensi, dan keterampilan yang dimiliki dalam menjalani kehidupan. Oleh karena itu, pendidikan didesain guna memberikan pemahaman dan meningkatkan prestasi belajar peserta didik (siswa).

Secara singkat tujuan pendidikan ialah untuk mencerdaskan kehidupan bangsa dan mengembangkan manusia
Indonesia seutuhnya, dengan ciri-ciri sebagai berikut: a) beriman dan bertaqwa kepada Tuhan Yang Maha Esa, b) berbudi pekerti luhur, c) memiliki pengatahuan dan keterampilan, d) sehat jasmani dan rohani, e) kepribadian yang mantap dan mandiri, f) bertanggung jawab terhadap masyarakat dan bangsa.

Berdasarkan tujuan pendidikan di atas maka diharapkan pendidikan di Indonesia dapat mencerdaskan kehidupan bangsa dan mengembangkan manusia indonesia seutuhnya. Manusia yang beriman dan bertaqwa terhadap Tuhan Yang Maha Esa. Berbudi pekerti luhur, memiliki keterampilan dan pengetahuan, kesehatan jasmani dan rohani, kepribadian yang mantap, mandiri serta 
rasa tanggung jawab kemasyarakatan dan kebangsaan.

Uraian di atas menunjukkan bahwa salah satu mata pelajaran yang dapat dikembangkan di Sekolah Dasar adalah mata pelajaran Ilmu Pengetahuan Alam (IPA). Mata pelajaran Ilmu Pengetahuan Alam (IPA) secara umum dipahami sebagai ilmu yang lahir dan berkembang lewat langkah-langkah observasi, perumusan masalah, penyusunan hipotesis, pengujian hipotesis melalui eksperimen, penarikan kesimpulan, serta penemuan teori dan konsep. Dapat pula dikatakan bahwa hakikat IPA adalah ilmu pengetahuan yang mempelajari gejala-gejala melalui serangkaian proses yang dikenal dengan proses ilmiah yang dibangun atas dasar sikap ilmiah dan hasilnya terwujud sebagai produk ilmiah yang tersusun atas tiga komponen terpenting berupa konsep, prinsip, dan teori yang berlaku secara universal (Trianto, 2010: 141).

Ilmu Pengetahuan Alam yang dasarnya tersusun atas tiga komponen yang berupa konsep, prinsip, dan teori pada jenjang pendidikan sekolah dasar mencakup tiga bidang ilmu dasar, yaitu biologi, fisika, dan kimia. Hal tersebut sejalan dengan ciri khas IPA sebagai mata pelajaran pada jenjang pendidikan dasar yang sifatnya terpadu (integrated) dari sejumlah mata pelajaran dengan tujuan agar mata pelajaran ini lebih bermakna bagi peserta didik sehingga pengorganisasian materi/ bahan pelajaran disesuaikan dengan lingkungan, karakteristik, dan kebutuhan peserta didik. Berdasarkan pengertian dan ciri khas dari mata pelajaran IPA tersebut, peserta didik diharapkan memperoleh pengalaman yang lebih luas dan mendalam pada bidang ilmu yang berkaitan.

Menurut Trianto (2009: 17) menyatakan bahwa pembelajaran hakikatnya adalah usaha sadar dari seorang guru untuk membelajarkan siswanya (mengarahkan interaksi siswa dengan sumber belajar lainya) dalam rangka mencapai tujuan yang diharapkan. Berdasarkan pengertian pembelajaran tersebut, pembelajaran tentunya tidak terlepas dari metode dan media pembelajaran yang mendukung pelaksanaannya.

Ditemukan kasus di lapangan bahwa pada pembelajaran Ilmu Pengetahuan Alam, peneliti (guru kelas V) selama ini guru hanya menggunakan metode ceramah saja dan tidak pernah menggunakan metode-metode pembelajaran lainnya. Selain itu dalam menjelaskan materi guru mengambil dari buku paket, membuatkan catatan tentang materi yang dijelaskan dengan mendikte kemudian dilanjutkan dengan memberikan tugas untuk mengerjakan soal-soal yang berkaitan dengan materi yang disampaikan tanpa ada kesempatan siswa untuk membentuk pengetahuannya sendiri.

Dari hasil observasi di atas dapat diketahui bahwa siswa kurang mampu memahami materi yang disampaikan dan merasa kesulitan ketika menjelaskan dan mengidentifikasi terhadap materi yang disampaikan. Siswa hanya berfikir secara abstrak dan berangan-angan terhadap apa yang disampaikan oleh guru. Kenyataan tersebut terjadi karena guru masih menggunakan metode ceramah. Kegiatan pembelajaran yang berpusat pada guru mengakibatkan siswa kurang aktif selama mengikuti pembelajaran. Guru kurang mengaktifkan siswa, sehingga siswa cenderung untuk mendengar, mencatat, mengerjakan tugas, sesekali jika guru memberikan pertanyaan siswa menjawab pertanyaan guru secara bersama-sama.

Berdasarkan temuan tersebut diperlukan upaya untuk memperbaiki kegiatan pembelajaran. Diantaranya dengan menciptakan suasana belajar yang nyaman dan menyenangkan serta menekankan pada keterlibatan siswa belajar secara cepat dan aktif. Salah satu metode pembelajaran yang dapat meningkatkan hasil belajar siswa adalah 
metode pembelajaran jigsaw. Metode pembelajaran jigsaw ialah suatu metode pembelajaran kooperatif yang mempunyai pembelajaran kelompok dengan membentuk tim ahli melakukan kegiatan belajar dengan cara bekerja sama dengan siswa lain untuk mencapai tujuan bersama (Rusman, 2011: 217).

$$
\text { Menurut Rusman (2011:219) }
$$

Metode jigsaw mempunyai keunggulan dalam pembelajaran IPA, yaitu meningkatkan rasa tanggung jawab siswa terhadap pembelajarannya sendiri dan juga pembelajaran terhadap orang lain, siswa tidak hanya mempelajari materi yang di berikan, tetapi juga harus siap dalam menyampaikan materi kepada kelompok lain, meningkatkan kerja sama artinya siswa bekerja sama dan mempunyai rasa tanggung jawab yang tinggi dalam memecahkan masalah yang di berikan guru. Adapun langkah-langkah dalam pembelajaran jigsaw (Kokom Komalasari, 2010 : 65) adalah sebagai berikut: 1) guru menyampaikan materi yang akan disajikan, 2) siswa dikelompokkan ke dalam 4 anggota tim, 3) Tiap orang dalam tim diberi bagian materi yang berbeda, 4) Tiap orang dalam tim diberi bagian materi yang ditugaskan, 5) anggota dari tim yang berbeda yang telah mempelajari bagian / subbab yang sama bertemu dalam kelompok baru (kelompok ahli) untuk mendiskusikan subbab mereka, 6) setelah selesai diskusi sebagai tim ahli, tiap anggota kembali ke kelompok asal dan bergantian mengajar teman satu tim mereka tentang subbab yang mereka kuasai dan tiap anggota lainnya mendengarkan dengan sungguhsungguh, 7) tiap tim ahli mempresentasikan hasil diskusi, 8) guru memberikan evaluasi, 9) penutup.

Berdasarkan uraian latar belakang diatas, guru kelas V (peneliti) untuk menemukan solusi permasalahan yang terjadi, dalam hal ini peneliti mengajukan pemecahan masalah melalui penelitian tindakan kelas dengan judul "Penerapan Metode Jigsaw Dapat Meningkatkan
Hasil Belajar IPA pada Materi Pesawat Sederhana di Kelas V SD Negeri Sumber Kecamatan Karangan Kabupaten Trenggalek Tahun 2016”.

\section{METODE}

Jenis penelitian ini adalah penelitian tindakan dan menggunakan desain Kemmis dan Mc Taggart (dalam Arikunto 2010:137). PTK adalah proses pengkajian masalah pembelajaran dalam kelas melalui refleksi diri dalam upaya menemukan dan memecahkan masalah tersebut dengan cara melakukan berbagai tindakan yang terencana dalam situasi nyata serta menganalisis setiap pengaruh dari perlakuan tersebut (Sanjaya 2009:26). Proses memecahkan masalah tersebut dilakukan secara bersiklus, dengan tujuan peningkatan hasil belajar siswa dan kinerja guru dalam pembelajaran di kelas. Praktik penelitian tindakan kelas dilakukan sebagai sarana penilaian hasil belajar siswa dalam pembelajaran dan sebagai pertimbangan dalam mengambil keputusan.

Penelitian Tindakan Kelas (PTK) ini dilakukan dengan menggunakan teknik deskripsif kualitatif. Untuk memperoleh data yang sesuai dengan keadaan yang ada di lapangan.

\section{HASIL DAN PEMBAHASAN}

Penerapan pembelajaran
kooperatif tipe jigsaw dalam
pembelajaran IPA kelas V SD Negeri
Sumber Kecamatan Karangan Kabupaten
Trenggalek, dilaksanakan melalui dua
siklus yaitu siklus 1 dan siklus 2.Adapun
penjelasan masing-masing diuraikan
sebagai berikut:

\section{A. Hasil Penelitian}

1. Pelaksanaan Siklus I

\section{a. Tahap Perencanaan tindakan siklus I}

Tahap perencanaan pada siklus 1 yang dilakukan pertama adalah menyusun dan membuat RPP. Pembuatan RPP 
didasarkan pada materi pesawat sederhana dan jenis-jenisnya.

Penilaian untuk siklus 1 diperoleh dari tes yang diberikan kepada siswa setelah pembelajaran dengan metode Jigsaw. Tes yang digunakan disesuaikan dengan indikator pembelajaran dengan jumlah soal sebanyak 10 yang dilaksanakan pada pertemuan ke-1. Soal tersebut diberikan untuk mengetahui hasil belajar siswa setelah penerapan pembelajaran dengan metode jigsaw.

Lembar instrumen observasi yang digunakan saat proses pembelajaran berlangsung untuk mengetahui proses belajar siswa, keterlaksanaan guru dalam mengajar (terlampir), serta keterlaksanaan metode yang digunakan (terlampir). Lembar instrumen observasi untuk mengetahui proses belajar siswa, menggunakan 5 aspek yaitu :(1) Perhatian, (2) Keaktifan membuat pertanyaan (3) Keaktifan dalam mengunakan jigsaw (4) Menjawab pertanyaan dan (5) Mencatat materi.

\section{b. Tahap Pelaksanaan tindakan siklus I}

Pelaksanaan tindakan siklus 1 ini, dilaksanakan berdasarkan rencana yang telah dibuat dengan dua pertemuan, pada pertemuan 1 pada hari Senin tanggal 18 Januari 2016 pukul 07.00-08.10 WIB, dan pertemuan 2 dilaksanakan pada hari Rabu tanggal 20 Januari 2016 pukul 07.00-08.10 WIB.

Pengamatan dilakukan bersamaan pada saat kegiatan belajar mengajar. Berdasarkan rencana pembelajaran yang telah disusun, maka pembelajaran dibagi menjadi tiga tahap yaitu: kegiatan awal, kegiatan inti, dan kegiatan akhir.

\section{c. Analisis Hasil Pengamatan Siswa dalam Proses Pembelajaran IPA dengan Menerapkan Metode Jigsaw}

Data ini merupakan hasil pengamatan yang dilakukan selama pembelajaran berlangsung pada pertemuan I sampai pertemuan ke II pada siklus pertama

Adapun tabel hasil penilaian aktifitas dalam pelaksanaan jigsaw pada siklus I (terlampir) adalah sebagai berikut:

Tabel 1. Hasil Pengamatan Proses

Pembelajaran Siswa pada Siklus I

\begin{tabular}{|c|l|c|c|}
\hline No & Nama Siswa & Jumlah & Skor \% \\
\hline 1 & Anggun & 5 & $55,5 \%$ \\
\hline 2 & Akmal & 4 & $44,4 \%$ \\
\hline 3 & Bintang & 4 & $44,4 \%$ \\
\hline 4 & Caputra & 4 & $44,4 \%$ \\
\hline 5 & Diasty & 8 & $88,8 \%$ \\
\hline 6 & Erma & 4 & $44,4 \%$ \\
\hline 7 & Elisa & 8 & $55,5 \%$ \\
\hline 8 & Endah & 4 & $88,8 \%$ \\
\hline 9 & Hasan & 4 & $44,4 \%$ \\
\hline 10 & Leny & 8 & $88,8 \%$ \\
\hline 11 & Manda & 4 & $44,4 \%$ \\
\hline 12 & Mira & 4 & $44,4 \%$ \\
\hline 13 & Novy & 5 & $55,5 \%$ \\
\hline 14 & Syahrul & 9 & $100 \%$ \\
\hline 15. & Sandy & 4 & $44,4 \%$ \\
\hline 16. & Sendi & 5 & $100 \%$ \\
\hline 17. & Tegar & 7 & $55,5 \%$ \\
\hline 18. & Wiwit & 5,7 & $61,35 \%$ \\
\hline 19. & Wulan & & \\
\hline Jumlah & 5 & $1165,7 \%$ \\
\hline Rata-rata & & 5 & \\
\hline
\end{tabular}

Keterangan:

Skor maksimal $=9$

$$
P a=\frac{\sum \text { nilai } a+\text { Enilai } b+\sum \text { nilai } c}{N}
$$

Deskriptor :

Keberanian

3 = jika siswa berani dalam bertanya dan menjawab pertanyaan

2 = jika siswa kurang berani dalam bertanya dan menjawab pertanyaan

$1=$ jika siswa tidak berani dalam bertanya dan menjawab pertanyaan

\section{Kerjasama}

3 = jika siswa dapat bekerja sama dengan temannya

2 = jika siswa kurang bekerja sama dengan temannya

$1=$ jika siswa tidak dapat bekerja sama dengan temannya 


\section{Keaktifan}

$3=$ jika siswa aktif mengikuti

pembelajaran

$2=$ jika siswa kurang aktif mengikuti

pembelajaran

$1=$ jika siswa tidak aktif mengikuti

pembelajaran

Berdasarkan hasil observasi aktivitas siswa pada proses pembelajaran IPA siswa kelas VI SD Negeri Sumber Kecamatan Karangan Kabupaten Trenggalek pada siklus 1 dengan menerapkan metode Jigsaw, untuk ratarata kelas diperoleh nilai sebesar $61,35 \%$ dengan rincian sebagai berikut: yang memperoleh kriteria tingkat aktivitas siswa sebesar $44,4 \%$ dengan keterangan kurang aktif sebanyak 9 siswa, yang memperoleh kriteria tingkat aktivitas siswa sebesar 55,5\% dengan keterangan cukup aktif sebanyak 4 siswa, yang memperoleh kreteria tingkat aktivitas siswa sebesar $77,7 \%$ dengan keterangan aktif sebanyak 1 siswa, sedangkan yang mendapat keterangan sangat aktif yaitu sebanyak 5 siswa dengan rincian 3 siswa memperoleh kriteria aktivitas siswa sebesar $88.8 \%$, dan 2 siswa kriteria tingkat aktivitas siswa sebesar $100 \%$.

\section{d. Hasil pengamatan kemampuan guru mengajar}

Selain siswa, peneliti yang bertindak sebagai guru juga dinilai oleh observer. Penilaian yang dilakukan mulai dari kemampuan mengajar sampai dengan keruntutan tahap-tahap pembelajaran yang dilakukan sesuai dengan RPP yang telah dibuat.

\section{e. Analisis Hasil evaluasi Siswa Siklus I dalam Pembelajaran IPA}

Setelah peneliti melaksanakan kegiatan pembelajaran pada Siklus I dengan menggunakan metode jigsaw, pada mata pelajaran IPA dengan KD yang diambil adalah 5.2 Menjelaskan Pesawat sederhana yang dapat membuat pekerjaan lebih mudah dan lebih cepat, maka didapatkan hasil penelitian pada Siklus I sebagai berikut:

Tabel 2. Daftar Nilai Siklus I

\begin{tabular}{|c|c|c|c|c|c|}
\hline \multirow{2}{*}{ No } & \multirow{2}{*}{$\begin{array}{l}\text { Nama } \\
\text { Siswa }\end{array}$} & \multirow{2}{*}{ Nilai } & \multirow{2}{*}{$\begin{array}{c}\text { Keterca } \\
\text { paian }\end{array}$} & \multicolumn{2}{|c|}{ Ketuntasan } \\
\hline & & & & Ya & Tidak \\
\hline 1. & Anggun & 62 & 70 & & $\sqrt{ }$ \\
\hline 2. & Akmal & 50 & 70 & & $\sqrt{ }$ \\
\hline 3. & Bintang & 72 & 70 & $\sqrt{ }$ & \\
\hline 4. & Caputra & 72 & 70 & $\sqrt{ }$ & \\
\hline 5. & Diasty & 77 & 70 & $\sqrt{ }$ & \\
\hline 6. & Erma & 70 & 70 & $\sqrt{ }$ & \\
\hline 7. & Elisa & 73 & 70 & $\sqrt{ }$ & \\
\hline 8. & Endah & 82 & 70 & $\sqrt{ }$ & \\
\hline 9. & Hasan & 35 & 70 & & $\sqrt{ }$ \\
\hline 10. & Leny & 72 & 70 & $\sqrt{ }$ & \\
\hline 11. & Manda & 96 & 70 & $\sqrt{ }$ & \\
\hline 12. & Mira & 54 & 70 & & $\sqrt{ }$ \\
\hline 13. & Novy & 92 & 70 & $\sqrt{ }$ & \\
\hline 14. & Syahrul & 72 & 70 & $\sqrt{ }$ & \\
\hline 15. & Sandy & 96 & 70 & $\sqrt{ }$ & \\
\hline 16. & Sendi & 76 & 70 & $\sqrt{ }$ & \\
\hline 17. & Tegar & 96 & 70 & $\sqrt{ }$ & \\
\hline 18 & Wiwit & 72 & 70 & $\sqrt{ }$ & \\
\hline 19. & Wulan & 77 & 70 & $\sqrt{ }$ & \\
\hline \multicolumn{2}{|c|}{ Jumlah } & 1.391 & & 11 & 8 \\
\hline \multicolumn{2}{|c|}{ Rata-rata } & 73,2 & & $\begin{array}{c}57,89 \\
\%\end{array}$ & $42,10 \%$ \\
\hline \multicolumn{2}{|c|}{$\begin{array}{l}\text { Prosentase } \\
\text { Ketuntasan }\end{array}$} & \multicolumn{4}{|c|}{$57,89 \%$} \\
\hline
\end{tabular}

Tabel 3. Data Ketuntasan Belajar Siswa dengan Penerapan Metode Jigsaw Siklus I

\begin{tabular}{clll}
\hline No. & Jenis Data & \multicolumn{2}{l}{ Jumlah Data } \\
\hline 1. & $\begin{array}{l}\text { Jumlah Siswa } \\
\text { yang Hadir }\end{array}$ & 19 & Siswa \\
\hline 2. & $\begin{array}{l}\text { Jumlah Siswa } \\
\text { Tuntas }\end{array}$ & Siswa $(57,89 \%)$ \\
\hline 3. & $\begin{array}{l}\text { Jumlah Siswa } \\
\text { Belum Tuntas }\end{array}$ & Siswa $(42,10 \%)$ \\
\hline
\end{tabular}

Data tabel 3 menunjukan jumlah siswa kelas V SD Negeri Sumber Kecamatan Karangan Kabupaten Trenggalek yang hadir sebanyak 19 siswa. Kriteria yang diberikan bahwa ketuntasan klasikal dikatakan berhasil jika mencapai $\leq 75 \%$. Hasil penelitian menunjukkan bahwa siswa tergolong tuntas belajar sebanyak 11 siswa $(57,89$ $\%$ ), dan siswa belum tuntas belajar sebanyak 8 siswa $(42,10 \%)$. Siklus pertama target keberhasilan penelitian yang mematok angka 70 untuk rata-rata kelas dan ketuntasan kelas $\leq 75 \%$ belum 
berhasil dipenuhi karena nilai ketuntasan klasikal yang diperoleh pada siklus I sebesar $57,89 \%$. Sehingga penelitian ini dilanjutkan pada siklus berikutnya.

\section{Pelaksanaan Siklus II}

\section{Perencanaan tindakan siklus II}

Perencanaan tindakan pada siklus II dilakukan berdasarkan refleksi pada tahap siklus I. Kegiatan perencanaan yang dilakukan adalah sebagai berikut: Peneliti menyiapkan rencana pelaksanaan pembelajaran dengan menerapkan metode Jigsaw. Materi yang akan dipelajari oleh siswa, yaitu konduktor dan isolator panas.

\section{Pelaksanaan tindakan siklus II}

Pelaksanaan tindakan siklus II ini, dilaksanakan berdasarkan rencana yang telah dibuat. Pelaksanaan siklus II dilaksanakan dengan dua pertemuan, untuk pertemuan 1 pada hari Senin tanggal 1 Pebruari 2016, pukul 07.0008.10 WIB. Sedangkan untuk pertemuan II dilaksanakan pada hari Rabu tanggal 3 Pebruari 2016, pukul 07.00-08.10 di ruang kelas V SD Negeri Sumber Kecamatan Karangan. Jumlah siswa tersebut adalah 19 siswa. Berdasarkan rencana pembelajaran yang telah disusun, maka pembelajaran dibagi menjadi tiga tahap yaitu: kegiatan awal, kegiatan inti, dan kegiatan akhir.

\section{c. Analisis Aktivitas Siswa dalam Pembelajaran IPA dengan Menerapkan Metode Jigsaw}

Penilaian aktivitas siswa dalam pelaksanaan jigsaw dilakukan oleh guru pengamat pada setiap kelompok juga menggunakan lembar observasi yang sama, aspek yang dinilai yaitu, penyampaian pendapat, kerjasama antar siswa, keaktifan siswa pada saat melakukan diskusi dan presentasi.

Hasil observasi aktivitas siswa yang diamati selama 2 (dua) kali pertemuan dan adapun tabel hasil penilaian aktifitas siswa dalam pelaksanaan jigsaw pada siklus II adalah sebagai berikut:

Tabel 4. Hasil Penilaian Aktivitas Siswa

Pelaksanaan Jigsaw Siklus II

\begin{tabular}{|c|l|c|c|}
\hline No & \multicolumn{1}{|c|}{ Nama Siswa } & Skor & Jumlah \\
\hline 1 & Anggun & 4 & $44,4 \%$ \\
\hline 2 & Akmal & 4 & $44,4 \%$ \\
\hline 3 & Bintang & 7 & $77,7 \%$ \\
\hline 4 & Caputra & 7 & $77,7 \%$ \\
\hline 5 & Diasty & 4 & $88,8 \%$ \\
\hline 6 & Erma & 5 & $44,4 \%$ \\
\hline 7 & Elisa & 5 & $55,5 \%$ \\
\hline 8 & Endah & 5 & $55,5 \%$ \\
\hline 9 & Hasan & 5 & $55,5 \%$ \\
\hline 10 & Leny & 9 & $100 \%$ \\
\hline 11 & Manda & 4 & $44,4 \%$ \\
\hline 12 & Mira & 9 & $100 \%$ \\
\hline 13 & Novy & 5 & $55,5 \%$ \\
\hline 14 & Syahrul & 9 & $100 \%$ \\
\hline 15. & Sandy & 4 & $44,4 \%$ \\
\hline 16. & Sendi & 9 & $100 \%$ \\
\hline 17. & Tegar & 7 & $77,7 \%$ \\
\hline 18. & Wiwit & 129 & $77,7 \%$ \\
\hline 19. & Wulan & 6,7 & $75,38 \%$ \\
\hline Jumlah & & \\
\hline Rata-rata & & & \\
\hline
\end{tabular}

Keterangan:

Skor maksimal $=9$

$$
P a=\frac{\text { Enilai } a+\text { Enilai } b+\sum \text { nilai } c}{N}
$$

\section{Deskriptor :}

\section{Keberanian}

$3=$ jika siswa berani dalam bertanya dan menjawab pertanyaan

$2=$ jika siswa kurang berani dalam bertanya dan menjawab pertanyaan

$1=$ jika siswa tidak berani dalam bertanya dan menjawab pertanyaan

\section{Kerjasama}

3 = jika siswa dapat bekerja sama dengan temannya

$2=$ jika siswa kurang bekerja sama dengan temannya

$1=$ jika siswa tidak dapat bekerja sama dengan temannya

\section{Keaktifan}

3 = jika siswa aktif mengikuti pembelajaran 
$2=$ jika siswa kurang aktif mengikuti pembelajaran

$1=$ jika siswa tidak aktif mengikuti pembelajaran.

\section{d. Pengamatan kemampuan guru mengajar}

Pada pembelajaran siklus II, peneliti yang bertindak sebagai guru juga dinilai oleh observer. Penilaian yang dilakukan mulai dari kemampuan mengajar sampai dengan keruntutan tahap-tahap pembelajaran yang dilakukan sesuai dengan RPP yang telah dibuat.

\section{e. Analisis Hasil Evaluasi Siswa Siklus II dalam Pembelajaran IPA dengan Metode Menerapkan Jigsaw}

Setelah peneliti melaksanakan kegiatan pembelajaran pada Siklus II dengan menggunakan metode jigsaw, pada mata pelajaran IPA dengan KD yang diambil adalah 5.2 Menjelaskan Pesawat Sederhana yang dapat membuat pekerjaan lebih mudah dan lebih cepat, maka didapatkan hasil penelitian pada Siklus II sebagai berikut:

Tabel 5. Daftar Nilai Siklus II

\begin{tabular}{|c|c|c|c|c|c|}
\hline \multirow[b]{2}{*}{ No } & \multirow[b]{2}{*}{$\begin{array}{l}\text { Nama } \\
\text { Siswa }\end{array}$} & \multirow[b]{2}{*}{ Nilai } & \multirow{2}{*}{$\begin{array}{c}\text { Keterca } \\
\text { paian }\end{array}$} & \multicolumn{2}{|c|}{ Ketuntasan } \\
\hline & & & & Ya & $\begin{array}{c}\text { Tida } \\
\mathbf{k}\end{array}$ \\
\hline 1. & Anggun & 62 & 70 & & $\sqrt{ }$ \\
\hline 2. & Akmal & 70 & 70 & $\sqrt{ }$ & \\
\hline 3. & Bintang & 62 & 70 & & $\sqrt{ }$ \\
\hline 4. & Caputra & 72 & 70 & $\sqrt{ }$ & \\
\hline 5. & Diasty & 77 & 70 & $\sqrt{ }$ & \\
\hline 6. & Erma & 70 & 70 & $\sqrt{ }$ & \\
\hline 7. & Elisa & 73 & 70 & $\sqrt{ }$ & \\
\hline 8. & Endah & 82 & 70 & $\sqrt{ }$ & \\
\hline 9. & Hasan & 72 & 70 & $\sqrt{ }$ & \\
\hline 10. & Leny & 72 & 70 & $\sqrt{ }$ & \\
\hline 11. & Manda & 96 & 70 & $\sqrt{ }$ & \\
\hline 12. & Mira & 76 & 70 & $\sqrt{ }$ & \\
\hline 13. & Novy & 92 & 70 & $\sqrt{ }$ & \\
\hline 14. & Syahrul & 72 & 70 & $\sqrt{ }$ & \\
\hline 15. & Sandy & 96 & 70 & $\sqrt{ }$ & \\
\hline 16. & Sendi & 76 & 70 & $\sqrt{ }$ & \\
\hline 17. & Tegar & 96 & 70 & $\sqrt{ }$ & \\
\hline 18 & Wiwit & 72 & 70 & $\sqrt{ }$ & \\
\hline 19. & Wulan & 77 & 70 & $\sqrt{ }$ & \\
\hline \multicolumn{2}{|c|}{ Jumlah } & 1500 & & 17 & 2 \\
\hline \multicolumn{2}{|c|}{ Rata-rata } & 78,9 & & $\begin{array}{l}89,4 \\
7 \%\end{array}$ & $\begin{array}{c}10,52 \\
\%\end{array}$ \\
\hline \multicolumn{2}{|c|}{$\begin{array}{l}\text { Prosentase } \\
\text { Ketuntasan }\end{array}$} & \multicolumn{4}{|c|}{$89,47 \%$} \\
\hline
\end{tabular}

Tabel 6 Data Ketuntasan Belajar Siswa dengan

Penerapan Metode Jigsaw Siklus II

\begin{tabular}{|c|l|cc|}
\hline No & \multicolumn{1}{|c|}{ Jenis Data } & \multicolumn{2}{|l|}{ Jumlah Data } \\
\hline 1. & $\begin{array}{l}\text { Jumlah Siswa yang } \\
\text { Hadir }\end{array}$ & 19 & Siswa \\
\hline 2. & $\begin{array}{l}\text { Jumlah Siswa } \\
\text { Tuntas }\end{array}$ & 17 & Siswa $(89,47 \%)$ \\
\hline 3. & $\begin{array}{l}\text { Jumlah Siswa } \\
\text { Belum Tuntas }\end{array}$ & 2 & Siswa $(10,52 \%)$ \\
\hline
\end{tabular}

Data tabel 6 menunjukan jumlah siswa kelas V SD Negeri Sumber Kecamatan Karangan Kabupaten Trenggalek yang hadir sebanyak 19 siswa (hadir semua). Kriteria yang diberikan bahwa ketuntasan klasikal dikatakan berhasil jika mencapai $\geq 75 \%$ dari jumlah yang memenuhi ketuntasan belajar. Hasil penelitian menunjukkan bahwa siswa tergolong tuntas belajar sebanyak 17 siswa $(89,47 \%)$, dan siswa belum tuntas belajar sebanyak 2 siswa $(10,52 \%)$.

\section{Pembahasan}

Peningkatan hasil belajar siswa dalam ranah kognitif terhadap pelajaran IPA melalui penerapan metode Jigsaw akan disajikan dalam bentuk tabel di bawah ini. Hasil dari tabel ini merupakan gambaran yang dapat menunjukkan peningkatan antara siklus 1 dan siklus 2 .

Tabel 7. Daftar Perbandingan Nilai Hasil Belajar antara Siklus I dan Siklus II

\begin{tabular}{|c|l|c|c|c|c|}
\hline No & $\begin{array}{c}\text { Nama } \\
\text { Siswa }\end{array}$ & $\begin{array}{c}\text { Nilai } \\
\text { Siklus I }\end{array}$ & $\begin{array}{c}\text { Ketun } \\
\text { tasan }\end{array}$ & $\begin{array}{c}\text { Nilai } \\
\text { Siklus } \\
\text { II }\end{array}$ & $\begin{array}{c}\text { Ketun } \\
\text { tasan }\end{array}$ \\
\hline 1. & Anggun & 72 & Tuntas & 62 & $\begin{array}{c}\text { Tidak } \\
\text { Tuntas }\end{array}$ \\
\hline 2. & Akmal & 40 & $\begin{array}{c}\text { Tidak } \\
\text { Tuntas }\end{array}$ & 70 & Tuntas \\
\hline 3. & Bintang & 72 & Tuntas & 62 & Tidak \\
\hline 4. & Caputra & 62 & $\begin{array}{c}\text { Tidak } \\
\text { tuntas }\end{array}$ & 72 & Tuntas \\
\hline 5. & Diasty & 78 & Tuntas & 77 & Tuntas \\
\hline 6 & Erma & 40 & $\begin{array}{c}\text { Tidak } \\
\text { Tuntas }\end{array}$ & 70 & Tuntas \\
\hline 7 & Elisa & 72 & Tuntas & 73 & Tuntas \\
\hline 8 & Endah & 76 & Tuntas & 82 & Tuntas \\
\hline 9. & Hasan & 72 & Tuntas & 72 & Tuntas \\
\hline 10. & Leny & 68 & $\begin{array}{c}\text { Tidak } \\
\text { Tuntas }\end{array}$ & 72 & Tuntas \\
\hline 11. & Manda & 93 & Tuntas & 96 & Tuntas \\
\hline 12. & Mira & 67 & $\begin{array}{c}\text { Tidak } \\
\text { Tuntas }\end{array}$ & 76 & Tuntas \\
\hline 13. & Novy & 65 & $\begin{array}{c}\text { Tidak } \\
\text { Tuntas }\end{array}$ & 92 & Tuntas \\
\hline
\end{tabular}




\begin{tabular}{|c|l|c|c|c|c|}
\hline 14. & Syahrul & 72 & Tuntas & 72 & Tuntas \\
\hline 15. & Sandy & 92 & Tuntas & 96 & Tuntas \\
\hline 16. & Sendi & 67 & $\begin{array}{c}\text { Tidak } \\
\text { Tuntas }\end{array}$ & 76 & Tuntas \\
\hline 17. & Tegar & 92 & Tuntas & 96 & Tuntas \\
\hline 18. & Wiwit & 90 & Tuntas & 72 & Tuntas \\
\hline 19. & Wulan & 76 & Tuntas & 77 & Tuntas \\
\hline
\end{tabular}

Tabel 8. Data Perbandingan Ketuntasan Belajar Siswa antara Siklus I dan Siklus II

\begin{tabular}{|c|c|c|c|}
\hline No. & $\begin{array}{c}\text { Jenis } \\
\text { Data }\end{array}$ & $\begin{array}{c}\text { Jumlah Data } \\
\text { Siklus I }\end{array}$ & $\begin{array}{c}\text { Jumlah Data } \\
\text { Siklus II }\end{array}$ \\
\hline 1. & $\begin{array}{c}\text { Jumlah } \\
\text { Siswa } \\
\text { yang }\end{array}$ & 19 siswa & 19 siswa \\
& Hadir & & \\
\hline 2. & $\begin{array}{c}\text { Jumlah } \\
\text { Siswa }\end{array}$ & 11 siswa & 17 siswa \\
& Tuntas & $(57,89 \%)$ & $(89,47 \%)$ \\
\hline 3. & $\begin{array}{c}\text { Jumlah } \\
\text { Siswa }\end{array}$ & 8 siswa & 2 siswa \\
& Belum & $(10,52 \%)$ \\
& Tuntas & & \\
\hline
\end{tabular}

Berdasarkan data hasil tes siklus 1 didapatkan rata-rata nilai kelas sebesar $57,89 \%$ hasil tes siklus 2 diperoleh ratarata nilai kelas $89,47 \%$. Hasil rata-rata nilai kelas pada siklus 1 dan siklus 2 diketahui hasil belajar siswa pada ranah kognitif dengan menerapkan metode jigsaw meningkat sebesar 31,58\%.

KKM yang ditetapkan oleh pihak sekolah pada mata pelajaran IPA adalah 70. Sehingga siswa yang mendapatkan nilai dibawah KKM dinyatakan tidak tuntas. Sebanyak 9 siswa memiliki nilai di bawah 70 pada siklus 1dan sebanyak 3 anak pada siklus 2 yang memiliki nilai di bawah 70. Jadi dapat disimpulkan ketuntasan hasil belajar antara siklus 1 dan siklus 2 telah mengalami peningkatan dengan menerapkan metode Jigsaw sebesar 31,58\%.

\section{DAFTAR PUSTAKA}

Arsyad, Azhar. 1997. Media Pembelajaran.Jakarta: PT.Raja Grafindo Persada.

Akbar, Sa'dun. 2008 Penelitian Tindakan Kelas (Filosofi, Metodologi, dan
Implementasinya), Jakarta: Surya Pena Gemilang.

Brotowidjojo, M.D. 1998. Penulisan Karangan Ilmiah. Jakarta: Penerbit Akademika Pressindo.

BSNP. 2006. Standar Kompetensi dan Kompetensi Dasar 2006 Mata Pelajaran Ilmu Pengetahuan Alam Sekolah Dasar Madrasah Ibtidaiyah Jakarta: Departemen Pendidikan Nasional.

Buku Materi Pokok Metode Penelitian (MKDU4411), Buku 5 Jakarta: Universitas Terbuka.

Dimyati dan Mudjiono. 2006. Belajar dan Pembelajaran, Jakarta : Rineka Cipta.

Hamalik, Oemar. 1994. Media Pendidikan.Bandung: Citra Aditya Bakti.

Haryono,dkk 2004. Sain Jilid S untuk SD.Jakarta: Penerbit Erlangga.

Hewitt,S. Et al. 2006. Menjelajahi dan Mempelaajari: Ilmu Pengetahuan dan Teknologi (Terjemahan). Bandung: Pakar Raya.

Ismail. 2008. Strategi Pembelajaran Agama Islam Berbasis PAIKEM. Semarang: Rasail

Indriati,E. 2001. Menulis Karya Ilmiah. Jakarta: Gramedia

Kemmis, S. dan Mc. Taggart, R. 1988. The Action Research Planner. Victoria Dearcin University Press.

Nasutin, Noehi dkk., 2006, Pendidikan IPA di SD, Universitas Terbuka.

Rositawaty, Aris Muharam. 2008. Senang Belajar Ilmu Pengetahuan 
121 Jurnal Pemikiran dan Pengembangan SD, Volume 6 Nomor 2, September 2018 hlm 113-121

Alam 5 (BSE), Pusat Perbukuan Depdiknas. Jakarta. Dunia Ilmu

Sutarno,Nano dkk., 2008, Materi dan Pembelajaran IPA SD, Universitas Terebuka. Wardani, I.G.A.K. 1997. Modul Laporan Penelitian dalam IGAK Wardani. 